\title{
PENGARUH LAMA PERENDAMAN STERILISASI EKSPLAN DAUN KARET (Hevea brasiliensis) SECARA IN VITRO
}

\author{
(The Effects Of Sterilize Soaking Time Of Rubber Leaf (Hevea Brasiliensis) In In Vitro)
}

\section{Linda Rahmawati dan Mila Lukmana}

Program Studi Budidaya Tanaman Perkebunan Politeknik Hasnur

Jl. Brigjend H.Hasan Basri KM.11 Ray 5 Barito Kuala 70582

Email : linda.polihasnur@yahoo.com

Article Submitted : 03-05-2019

Article Accepted : 03-10-2019

\begin{abstract}
Previous research found sterilization formulations for the best rubber leaf explants. The aim of this study was to get the best treatment for the best soaking time formulation in sterilizing rubber leaf explants. This study uses the same concentration of sterilization with the soaking time variations as follows: P1 (control); P2 (15 minutes fungicide, 15 minutes bactericides, Bayclin $20 \% 1$ minute, $5 \%$ bayclin for 5 minutes and 70\% alcohol 0.5 minutes), P3 (30 minutes fungicide, bactericide 30 minutes, Bayclin 20\% 2 minutes, Bayclin $5 \%$ for 10 minutes and Alcohol 70\% 1 minute); P4 (45 minutes Fungicide, Bactericide 45 minutes, Bayclin 20\% 3 minutes, Bayclin 5\% for 15 minutes and Alcohol 70\% 2 minutes) and P5 (Fungicide 60 minutes, Bactericide 60 minutes, Bayclin 20\% 4 minutes, Bayclin 5\% for 20 minutes and Alcohol 70\% 3 minutes). Data analysis is carried out in two ways, namely qualitatively and quantitatively. Qualitative data is descriptive. While quantitatively, data is analyzed with table, graphs and formulas. The results obtained that the fastest contamination occured on day 6 after sowing, namely tratment P1 with the number of contaminated explants as many as 4 units of explants. P4 treatment is the best treatment where fungal contamination is $13.3 \%$ and bacterial contamination is $40 \%$, contaminations of explants is $50 \%$ and media contamination is $20 \%$.
\end{abstract}

Key words : Soaking time, sterilization, rubber leaf explants.

\section{PENDAHULUAN}

Tingginya kontaminasi merupakan salah satu permasalahan yang sering kali ditemui dalam kultur jaringan. Menurut Moradpour, dkk (2016), kontaminasi sering ditemukan pada kultur tanaman karet. Perendaman eksplan pada bahan sterilan yang sifatnya toksik harus benar-benar diperhatikan pada konsentrasi dan waktu perendaman. Berdasarkan penelitian terdahulu oleh Lukmana dan Rahmawati (2016) bahwa dengan perendaman eksplan pada fungisida 2 g/l selama 30 menit, bakterisida 2 g/l selama 30 menit, Clorox Bayclin ${ }^{\mathrm{TM}}$ 20\% selama 10 menit, Clorox Bayclin ${ }^{\mathrm{TM}} 5 \%$ selama 5 menit, dan alkohol $70 \%$ yang ditambah 1 tetes Tween 80 selama 3 menit memberikan hasil terbaik yaitu $66,67 \%$ eksplan tidak terkontaminasi. Selain itu, dalam penelitian selanjutnya dengan perlakuan direndam dalam alkohol $70 \%$ selama 1 menit, kemudian dalam $\mathrm{H}_{2} \mathrm{O}_{2} \quad 17,6 \%$ selama 20 menit dapat mengatasi kontaminasi eksplan daun karet sebesar 65\% (Lukmana dan Rahmawati, 2016).

Dalam penelitian ini beberapa bahan sterilan yang sudah terbukti dapat mengatasi kontaminasi pada eksplan daun karet akan dibuat konsentrasi bertingkat dan lama waktu 
perendaman. Dengan demikian, harapannya dapat diperoleh konsentrasi dan waktu yang optimal untuk meminimalisir kontaminasi pada eksplan daun karet maupun medianya.

Tujuan penelitian ini adalah mendapatkan perlakuan terbaik lama perendaman yang efektif pada sterilisasi untuk meminimalisir kontaminasi eksplan.

\section{METODE PENELITIAN}

Penelitian ini akan dilaksanakan pada bulan Maret s/d Juli 2018 di Laboratorium Kultur Jaringan SMK Pertanian Pembangunan, Banjarbaru.

Alat-alat yang digunakan dalam penelitian ini meliputi botol kultur, autoklaf, kompor gas, panci, alumunium foil, bunsen, pisau scalpel, pinset,pipet volumetrik, $\mathrm{pH}$ meter, neraca analitik, Laminar air flow cabinet (LAFC), oven, plastik/ wrapping pack, sprayer, gelas ukur, erlenmeyer, labu ukur, corong kaca, dan sudip.

Bahan yang digunakan dalam penelitian ini adalah Woody Plant Medium (WPM), daun dari bibit karet klon PB 260 yang masih muda dan baru membuka, bahan yang digunakan untuk sterilisasi adalah fungisida (2 g/l), bakterisida (2 g/l), Alkohol 70\%, Clorox (Bayclin ${ }^{\mathrm{TM}}$ ) 20\% (v/v), Clorox (Bayclin ${ }^{\mathrm{TM}}$ ) 5\% (v/v), Alkohol 70\% (v/v), Tween 80, bahan bakar untuk Bunsen menggunakan adalah spiritus.

\section{Sterilisasi Alat}

Peralatan disterilisasi dengan sterilisasi kering menggunakan oven pada suhu $180^{\circ} \mathrm{C}$ selama 2 jam. Peralatan yang terbuat dari bahan gelas dan peralatan logam/stainless dicuci dengan detergen hingga bersih dan dikeringkan. Selanjutnya peralatan gelas dibungkus dengan menggunakan kertas pembungkus, sedangkan alat stainless yang akan digunakan dalam inokulasi dimasukkan dalam wadah stainless/bak instrumen. Peralatan yang telah disiapkan dimasukkan ke dalam oven. Setelah 2 jam, peralatan dikeluarkan dan langsung dimasukkan ke dalam LAF.

\section{Pembuatan Woody Plant Medium (WPM)}

Pembuatan media WPM sebanyak 1000 $\mathrm{ml}$ dengan menambahkan $30 \mathrm{~g}$ sukrosa, $7 \mathrm{~g}$ agar dan $2 \mathrm{~g}$ arang aktif serta 2,4-D 1,5 ppm. Kemudian, melakukan sterilisasi media dengan memasukkan ke dalam autoklaf untuk disterilisasi selama 15 menit terhitung semenjak suhu mencapai $121{ }^{\circ} \mathrm{C}$ dengan tekanan 1 atm. Setelah itu menyimpan (menginkubasi) botol-botol kultur pada rakrak kultur 1-2 minggu sebelum digunakan.

\section{Perlakuan Sterilisasi Eksplan}

Perlakuan sterlisasi eksplan, yaitu 5 perlakuan variasi waktu perendaman. Setiap perlakuan dibuat 5 unit percobaan dan diulang sebanyak 3 kali. Sehingga penelitian ini menggunakan 75 satuan percobaan. Setiap satuan percobaan terdiri atas 2 eksplan yang diamati. Dengan demikian, jumlah eksplan yang diamati sebanyak 150 eksplan. Sebelum eksplan daun diberikan perlakuan terlebih dahulu direndam dalam larutan asam sitrat 30 $\mathrm{mg} / \mathrm{L}$ selama 30 menit untuk meminimalisasi terjadinya browning. Perlakuan yang diujikan kepada eksplan sebagai berikut:

1. Perlakuan 1 (P1/Kontrol), eksplan daun karet dicuci dengan detergen kemudian dibilas dengan air mengalir. Kemudian eksplan ditabur apda medium.

2. Perlakuan 2 (P2), eksplan daun karet dicuci dengan detergen kemudian dibilas dengan air mengalir. Fungisida (2g/l) selama 15 menit kemudian bilas aquades steril 2 kali, Bakterisida (2g/l) selama 15 menit kemudian bilas aquades steril 2 kali, Bayclin 20\%, 1 menit kemudian bilas aquades steril 2 kali, Bayclin 5\% selama 5 menit kemudian bilas aquades steril 2 kali. Terakhir rendam Alkohol $70 \%$ selama 0,5 menit kemudian bilas aquades steril 3 kali. Selanjutnya eksplan ditabur dalam medium.

3. Perlakuan 3 (P3), eksplan daun karet dicuci dengan detergen kemudian dibilas dengan air mengalir. Fungisida (2g/l) selama 30 menit kemudian bilas aquades steril 2 kali, Bakterisida (2g/l) selama 30 menit kemudian bilas aquades steril 2 
kali, Bayclin 20\%, 2 menit kemudian bilas aquades steril 2 kali, Bayclin 5\% selama 10 menit kemudian bilas aquades steril 2 kali. Terakhir rendam Alkohol $70 \%$ selama 1 menit kemudian bilas aquades steril 3 kali. Selanjutnya eksplan ditabur dalam medium.

4. Perlakuan $4(\mathrm{P} 4)$, eksplan daun karet dicuci dengan detergen kemudian dibilas dengan air mengalir. Fungisida (2g/l) selama 45 menit kemudian bilas aquades steril 2 kali, Bakterisida (2g/l) selama 45 menit kemudian bilas aquades steril 2 kali, Bayclin 20\%, 3 menit kemudian bilas aquades steril 2 kali, Bayclin 5\% selama 15 menit kemudian bilas aquades steril 2 kali. Terakhir rendam Alkohol $70 \%$ selama 2 menit kemudian bilas aquades steril 3 kali. Selanjutnya eksplan ditabur dalam medium.

5. Perlakuan 5 (P5), eksplan daun karet dicuci dengan detergen kemudian dibilas dengan air mengalir. Fungisida (2g/l) selama 1 jam kemudian bilas aquades steril 2 kali, Bakterisida (2g/l) selama 1 jam kemudian bilas aquades steril 2 kali, Bayclin 20\%, 4 menit kemudian bilas aquades steril 2 kali, Bayclin 5\% selama 20 menit kemudian bilas aquades steril 2 kali. Terakhir rendam Alkohol 70\% selama 3 menit kemudian bilas aquades steril 3 kali. Selanjutnya eksplan ditabur dalam medium.

\section{Analisis Data}

Penelitian dilakukan secara bertahap dan bersifat eksplorasi. Oleh karena itu, analisa data dilakukan dengan dua cara yaitu secara kualitatif dan secara kuantitatif. Data dianalisa dengan tabel dan rumus untuk perhitungan prosentase jenis kontaminasi jamur, prosentase jenis kontaminasi bakteri, prosentase kontaminasi pada eksplan, dan prosentase kontaminasi pada media.

\section{HASIL DAN PEMBAHASAN}

Sterilisasi eksplan daun karet pada penelitian ini menggunakan bahan kimia yaitu detergen cair, alkohol $70 \%$, betadine, Clorox $\left(\right.$ Bayclin $\left.^{\mathrm{TM}}\right)$, bakterisida, fungisida dan aquades steril. Setiap formula pada perlakuan sterilisasi diawali dengan merendam dalam detergen yang berfungsi membuang lapisan lilin pada permukaan jaringan agar penetrasi desinfektan lebih mudah serta mencegah terbentuknya gelembung udara yang dapat menutupi permukaan jaringan (Wetherell, 1982; Gunawan, 2007).

Tabel 1. Prosentase kontaminasi dan jenis kontaminan

\begin{tabular}{lrrrr}
\hline Perlakuan & Kontaminan jamur (\%) & $\begin{array}{c}\text { Kontaminan bakteri } \\
(\%)\end{array}$ & $\begin{array}{c}\text { Kontaminasi Eksplan } \\
(\%)\end{array}$ & $\begin{array}{c}\text { Kontaminasi media } \\
(\%)\end{array}$ \\
\hline P1 & 100.0 & 80.0 & 100.0 & 100.0 \\
P2 & 73.3 & 0.0 & 86.7 & 73.3 \\
P3 & 53.3 & 20.0 & 66.7 & 60.0 \\
P4 & 13.3 & 40.0 & 50.0 & 20.0 \\
P5 & 46.7 & 13.3 & 56.7 & 33.3 \\
\hline
\end{tabular}

Keterangan :

$\left(^{*}\right)$ : Browning tidak terlihat pada eksplan dan media karena tertutupi oleh jamur

Parameter yang diamati dalam penelitian ini meliputi : prosentase kontaminan jamur, prosentase kontaminan bakteri, prosentase kontaminasi pada eksplan dan prosentase kontaminasi pada media (Tabel 1).
Pengamatan dilakukan dari hari pertama setelah tabur (1 HST) hingga hari ke 35 setelah tabur (35 HST). Pengamatan menunjukkan bahwa setiap perlakuan menunjukkan kontaminasi yang berbeda- 
beda. Jumlah eksplan yang terkontaminasi dapat dilihat pada Tabel 2 dan grafik pengaruh perlakuan terhadap kontaminasi disajikan pada Gambar 2.

Tabel 2. Jumlah Unit Perlakuan yang Terkontaminasi

\begin{tabular}{cccccccc}
\hline \multirow{2}{*}{ Perlakuan } & \multicolumn{7}{c}{ Jumlah eksplan yang terkontaminasi pada hari ke- } \\
\cline { 2 - 8 } & 6 & 9 & 13 & 19 & 24 & 26 & 35 \\
\hline P1 & 10 & 10 & 30 & 30 & 30 & 30 & 30 \\
P2 & 4 & 8 & 26 & 26 & 26 & 26 & 26 \\
P3 & 0 & 2 & 18 & 20 & 20 & 20 & 20 \\
P4 & 0 & 2 & 15 & 15 & 15 & 15 & 15 \\
P5 & 0 & 6 & 16 & 16 & 16 & 17 & 17 \\
\hline
\end{tabular}

Tabel 2 menjelaskan kecepatan waktu kontaminasi dan jumlah eksplan yang terkontaminasi. Kontaminasi paling cepat terjadi 6 HST pada perlakuan P1 dengan jumlah eksplan terkontaminasi sebanyak 10 eksplan dan P2 sebanyak 4 eksplan. Kemudian pada hari ke 9, perlakuan P3 dan P4 masing-masing sebanyak 2 eksplan dan
P5 sebanyak 6 eksplan yang terkontaminasi. Kecepatan kontaminasi dan banyaknya eksplan yang terkontaminasi dipengaruhi oleh beberapa faktor diantaranya, kondisi ruang inkubasi yang kurang steril, teknis sterilisasi eksplan dan faktor genetik dari eksplan itu sendiri.

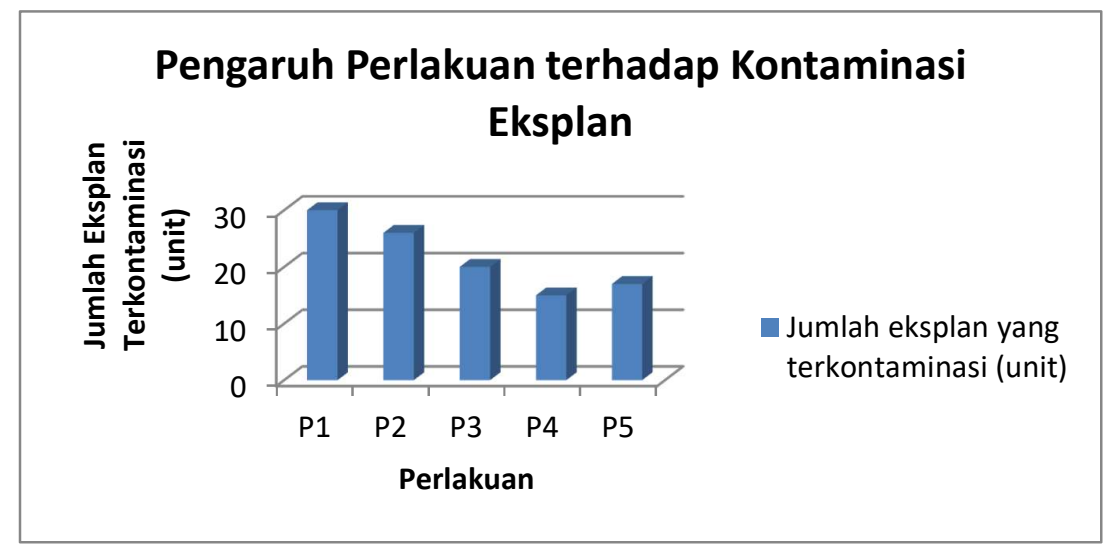

Gambar 1. Grafik pengaruh perlakuan terhadap kontaminasi eksplan

Berdasarkan Gambar 1 terlihat bahwa dari 30 eksplan yang ditabur pada setiap perlakuan, perlakuan P4 merupakan perlakuan paling efektif dalam meminimalisir kontaminasi baik jamur maupun bakteri. Hal tersebut juga terlihat pada Tabel 2 dimana hingga pengamatan 35 HST jumlah eksplan terkontaminasi berturutturut mulai dari paling sedikit yaitu P4 sebanyak 15 eksplan, P5 sebanyak 17 eksplan, P3 sebanyak 20 eksplan, P2 sebanyak 26 eksplan dan P1 sebanyak 30 eksplan. Gambar 2, memperlihatkan bahwa kontaminasi tidak selalu menyerang pada kedua eksplan namun dapat terjadi hanya pada satu eksplan. Dalam dua unit eksplan, tidak selalu sama morfologinya, seperti tulang daun yang lebih besar sehingga kontaminasi dapat terjadi hanya pada satu unit eksplan. Menurut Seneviratne et al. 
(1995), terdapat sejumlah besar bakteri dan fungi yang berasosiasi dengan jaringan tanaman, terutama pada bagian tanaman yang bergetah seperti karet. Getah pada tulang daun lebih banyak dibandingkan pada helai daunnya, hal ini sejalan

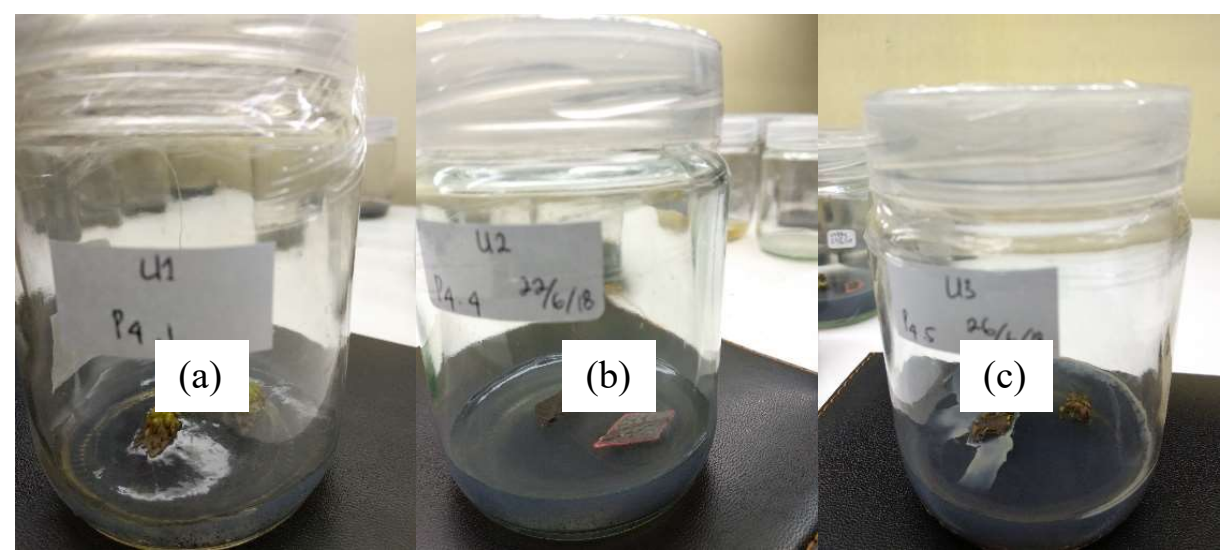

Gambar 2. Hasil perlakuan P4 (a) Tidak terkontaminasi sama sekali; (b) Kontaminasi hanya pada 1 eksplan; (c) Kontaminasi pada 1 eksplan dan media

dengan hasil penelitian Admojo dan Prasetyo (2016) bahwa dengan perendaman fungisida selama 30 hingga 60 menit, kontaminasi pada eksplan midrib atau tulang daun sebesar $21,33 \%$ dan $21,67 \%$ sedangkan pada eksplan helaian daun atau petiol, kontaminasi dapat ditekan sebesar 33\%.

\section{Jenis kontaminan}

Jamur merupakan mikroorganisme yang sangat cepat pertumbuhannya dengan menggunakan spora. Pada kondisi aseptis, spora dapat tumbuh apalagi jika media yang ditumbuhi jamur kaya akan nutrisi. Pada penelitian ini kontaminan didominasi oleh jamur pada semua perlakuan kecuali perlakuan P4. Pada Perlakuan P4 kontaminasi jamur sebesar $13.3 \%$, sedangkan kontaminasi bakteri sebesar 40\% (Tabel 1). Kontaminasi eksplan yang disebabkan bakteri ditandai dengan munculnya lendir dan atau koloni bakteri di sekeliling eksplan atau di atas permukaan eksplan. Bakteri merupakan mikroba yang hidup di dalam sel atau ruangan antarsel tanaman (endofitik) kebanyakan dari tanaman sumber eksplan dan sulit diatasi dengan sterilisasi permukaan (Yusnita, 2003 dalan Pancaningtyas dan Cahya, 2011). Oleh sebab itu, koloni bakteri sering belum muncul pada saat pertama kali eksplan baru dikulturkan.

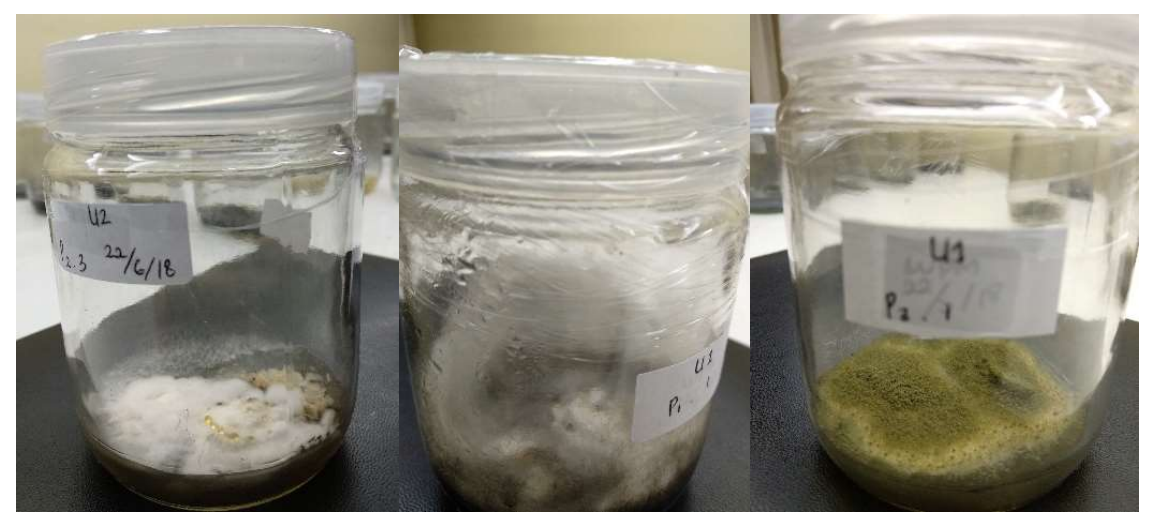

Gambar 3. Kontaminasi kultur oleh jamur 
Kontaminasi jamur dapat muncul mulai bagian tepi media dan permukaan eksplan. Kontaminasi jamur pada eksplan umumnya cukup cepat dan berat hingga menutup permukaan ekplan dan media (Gambar 3). Kontaminasi kultur eksplan daun karet oleh bakteri dapat dilihat pada Gambar 4 .

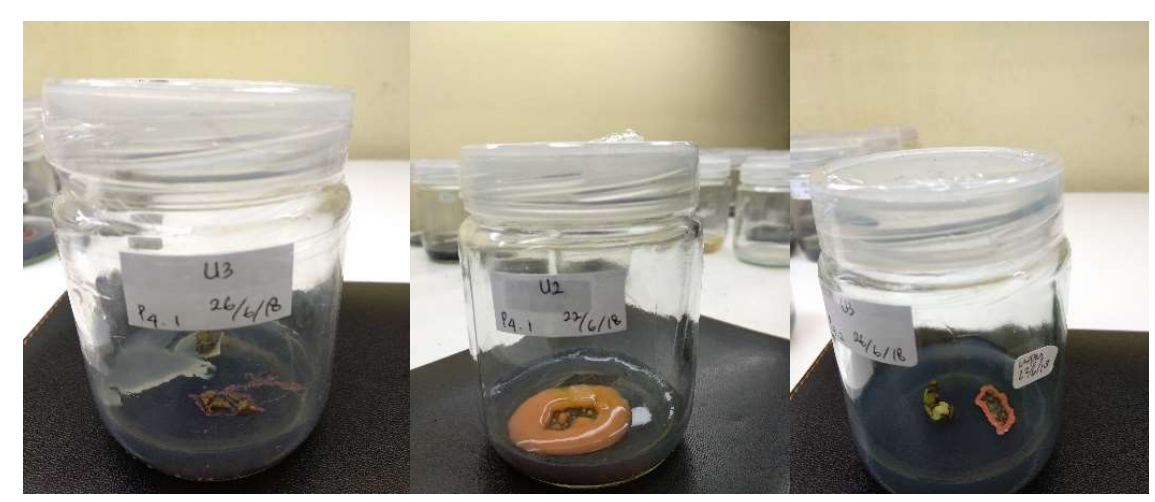

Gambar 4. Kontaminasi kultur oleh jamur dan bakteri

Pengamatan selama 35 HST, hal yang menarik terdapat pada perlakuan P2, dimana eksplan hanya terkontaminasi oleh jamur sebesar 73,3\%, sedangkan kontaminan bakteri tidak ditemukan. Hal ini kemungkinan, miselium dari jamur menutupi permukaan bakteri, sehingga kontaminasu bakteri hamper tidak terlihat. Dalam hal ini, perlunya formulasi yang tepat antara penambahan dosis bakterisida dan fungisida untuk meminimalisir kontaminasi jamur dan bakteri.

Kontaminasi dapat berasal dari internal maupun eksternal. Pada penelitian ini, kontaminasi yang terjadi merupakan kontaminasi internal karena lebih banyak terjadi pada hari ke 13 - 35 HST (Tabel 2). Hal ini karena eksplan daun karet adalah tanaman berkayu yang rentan terhadap kontaminasi karena berasal dari lapang, walaupun pencegahan awal sudah dilakukan dengan penyemprotan Dithane pada saat persiapan bahan tanam. Kontaminasi secara internal merupakan kontaminan yang terdapat pada jaringan tanaman, sedangkan kontaminasi eksternal berada di permukaan eksplan (Zulkarnain, 2009 dalam Rodinah dkk, 2016). Menurut Shofiyani dan Damajanti (2015), kontaminasi eksternal terjadi jika waktu penyerangan kurang dari 10 hari setelah tabur, jika lebih dari 10 hari setelah tabur termasuk kontaminasi internal. Resigia dan Herman (2017) menambahkan, eksplan yang diambil dari lapangan mengandung banyak mikroorganisme pengkontaminan.

\section{Kontaminasi pada eksplan dan media}

Media kultur sangat mendukung pertumbuhan mikroorganisme karena mengandung air, sumber karbon, sumber mineral, sumber nitrogen dan vitamin (Waluyo, 2004 dalam Oratmangun, Pandianganan dan Kandou, 2017). Sehingga tidak menutup kemungkinan kontaminan dalan kultur berasal dari media. Kontaminasi media dapat disebabkan karena kondisi yg kurang aseptik baik tempat kerja, alat dan orang yang mengerjakan (Oratmangun dkk, 2017). Kontaminasi dapat terjadi pada eksplan maupun media (Gambar 5).

Mikroorganisme yang muncul pada media akan menyerang eksplan melalui luka akibat pemotongan dan penanganan waktu sterilisasi (Oratmangun, Pandianganan dan Kandou, 2017). Pada penelitian ini, kontaminasi dapat terjadi pada eksplan saja tanpa mengkontaminasi media. Namun, jika kontaminasi terjadi pada media maka eksplan 
juga ikut terkontaminasi, tidak terdapat

kontaminasi yang terjadi hanya pada media.

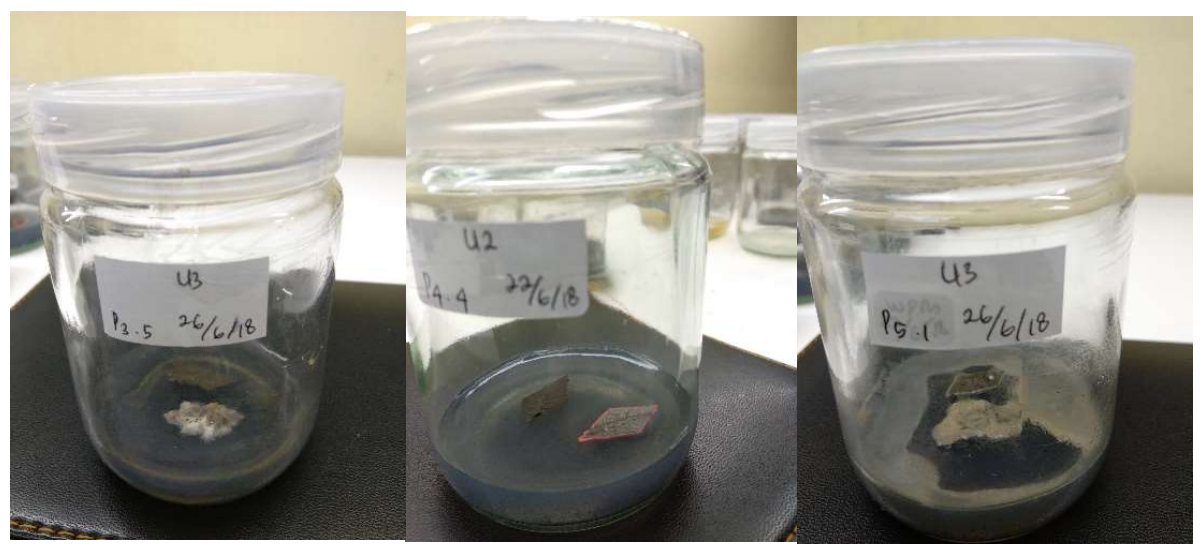

Gambar 5. Kontaminasi pada eksplan dan media

\section{KESIMPULAN}

Kesimpulan yang diperoleh pada penelitian ini sebagai berikut:

1. Kontaminasi tercepat terjadi pada hari ke 6 setelah tabur yaitu perlakuan P1 dengan jumlah eksplan terkontaminasi sebanyak 10 eksplan dan P2 sebanyak 4 eksplan.

2. Perlakuan P4 merupakan perlakuan terbaik dimana kontaminasi jamur sebesar $13,3 \%$ dan kontaminasi bakteri sebesar $40 \%$, kontaminasi pada eksplan $50,0 \%$ dan kontminasi pada media $20,0 \%$.

\section{DAFTAR PUSTAKA}

Admojo, L. dan N.E. Prasetyo. 2016. Pengaruh Sterilan terhadap Tingkat Kontaminasi pada Kultur Petiol dan Midrib Daun Tanaman Karet. Jurnal Penelitian Karet Vol. 34 (2): 151-164

Gunawan, I. (2007). Perlakuan Sterilisasi Eksplan Anggrek Kuping Gajah (Bulbophyllum beccarii Rchb.f) dalam Kultur In-Vitro. Bogor: IPB.

Lukmana, M., dan Rahmawati, L. 2016. Pengaruh Perlakuan Sterilisasi terhadap Kontaminasi pada Eksplan Daun Karet (Hevea brasiliensis) Klon
PB 260 dalam Kultur In Vitro. Jurnal Agrisains. Volume 02 No.1, 6-12.

Lukmana, M., dan Rahmawati, L. 2016. Efektifitas Beberapa Bahan Sterilan pada Eksplan Daun Tanaman Karet (Hevea brasiliensis) dalam Kultur In Vitro. Laporan Penelitian Dosen Pemula. Budidaya Tanaman Perkebunan, Politeknik Hasnur.

Moradpour M, Aziz M.A., and Abdullah S.N.A. 2016. Establishment of in vitro Culture of Rubber (Hevea brasiliensis) from Field-derived Explants: Effective Role of Silver Nanoparticles in Reducing Contamination and Browning. Journal of Nanomedicine \& Nanotechnology. Volume 7, Issue 3

Oratmangun, K.M., D. Pandiangana dan F.E., Kandou. 2017. Deskripsi Jenis-jenis Kontaminan dari Kultur Kalus Catharanthus roseus (L.) G. Don. Jurnal MIPA UNSRAT Online. 6 (1): 47-52.

Pancaningtyas, Sulistyani dan Cahya Ismayadi. (2011). Sterilisasi Ulang pada Perbanyakan Somatic Embryogenesis Kakao (Theobroma cacao L.) untuk 
Penyelamatan Embrio Terkontaminasi. Pelita Perkebunan, 27 (1), Edisi April 2011

Resigia, E., dan E. Herman. 2017. Pengaruh Jenis dan Lama Perendaman Bahan Sterilan terhadap Eksplan Anter Gambir (Uncaria gambir (Hunter) Roxb.). Jurnal Bibiet 2(2): 44-48.

Rodinah, F. Razie, D. Naemah dan A. Fitriani. 2016. Respon Bahan Sterilan pada Eksplan Jelutung Rawa (Dyra lowii). Jurnal Hutan Tropis. 4 (3): 24245
Seneviratne, P., A.W. Flegmann and G. A. S. Wijesekara. 1995. The Problem of Surface Sterilization of Shoot Materials of Hevea. Jl. Rubb. Rest. Inst. Sri Lanka. 75 (1): 51-60.

Shofiyani, A., \& Hajoeningtijas, O. D. 2015. Pengembangan Metode Sterilisasi pada Berbagai Eksplan Guna Meningkatkan Keberhasilan Kutur Kalus Kencur (Kaemferia galangal L) untuk Meningkatkan Keberhasilan Kultur Kalus. Agritech. 